\title{
Effect of Baypamun Treatment on Aujeszky's Disease Virus (ADV) Transmission in Pigs
}

N. BIUK-RUDAN, L. ŠVER, I. VALPOTIĆ, I. VRBANAC, J. MADIĆ, Ž. ŽUPANČIĆ, N. VIJTIUK, Ž. PAVIČIĆ

Department of Microbiology and Infectious Diseases, Veterinary Faculty, University of Zagreb, Croatia

Received June 20, 2003

Accepted February 11, 2004

Abstract

Biuk-Rudan, N., L. Šver, I. Valpotić, I. Vrbanac, J. Madić, Ž. Župančić, N. Vijtiuk, Ž. Pavičić: Effect of Baypamun Treatment in Aujeszky's Disease Virus (ADV) Transmission in Pigs. Acta Vet. Brno 2004, 73: 59-68.

The effect of Baypamun treatment in Aujeszky's disease virus (ADV) transmission from pigs challenged with virulent ADV was evaluated. Twenty 6-week-old crossbred pigs were divided into four equal groups and subjected to either vaccination or Baypamun treatment or challenge infection with ADV. The pigs of group I were vaccinated with $\mathrm{gE}^{-}$vaccine against Aujeszky's disease (Ayvac, Pliva, Zagreb, Croatia), the pigs of group II were treated by Baypamun as a non-specific immunostimulating agent, those of group III were inoculated with a virulent strain of Aujeszky's disease virus strain NIA-3, and group IV was used as control. After challenge infection of pigs of group III, all other groups were housed together. The amount of total antibodies and $\mathrm{gE}$ antibodies to Aujeszky's disease virus in sera of tested piglets was determined by immunoenzyme test. Isolation of PBL and lymphocyte stimulation test also was carried out. Our results indicate that pigs of groups I and II were better protected from, or less affected by, contact infection, respectively. Significantly higher mortality was detected in pigs of group III than in any other group. In this group, the most extensive pathomorphologic changes were also found. However, they were similar in group II and group IV. The former group of pigs had a lower incidence of diarrhoea $(0 / 5: 2 / 5)$ and increased reactivity of $\mathrm{T}$ and $\mathrm{B}$ cells compared to controls (group IV). Although Baypamun did not affect specific antibody production, the obtained results are encouraging, with regard to the non-specific immunostimulatory effect of BPM in pigs exposed to contact ADV infection.

Aujeszky's disease virus, Baypamun, vaccination, challenge infection, pigs

Aujeszky's disease virus (ADV) is an alphaherpesvirus that causes Aujeszky's disease or pseudorabies. A wide range of domestic and wild animals is susceptible to infection with this virus but pigs are a natural host of ADV. The first introduction of ADV in a herd results in an acute, often fatal infection of young piglets. Infection at an older age induces nervous and respiratory symptoms and sometimes reproductive disorders (Mettenleiter 1996).

The presence of ADV in breeding prevails with its latency and possibility of reactivation and re-excretion in the environment (Kluge et al. 1999). Vaccination reduces clinical signs and shedding of the virulent virus, but usually does not prevent replication of the ADV, nor establishment of latency after infection (Kluge et al. 1999). In addition, virus infection, latency and reactivation in the face of apparently strong immunity suggest that ADV has evolved viral mechanisms of immunosuppression (Hahn 1991). Inhibition of cell-mediated immune response was more pronounced than the inhibition of antibody. At the cellular level, ADV is able to infect and functionally disarm both macrophages and, selectively, certain types of leukocytes (Hahn 1991). Such deficiency in young pig leukocytes was found to be related to the decreased ability of their neutrophils to bind antibody-sensitized target cells

Address for correspondence:

Dr.Nevenka Biuk-Rudan 
(El-Awar and Hahn 1993). In peripheral blood mononuclear cells the ADV genome was amplified during the acute phase of infection (Balasch et al. 1998).

Vaccination of pigs against Aujeszky's disease (AD) with modified live virus or inactivated virus vaccines induces neutralizing antibodies and sensitized new lymphocytes in blood and lymphoid organs, but confers only partial protection. Systemic immunity seems not to be related to protection (V an Zaane et al. 1989). The discovery of marker vaccines, which lack a non-essential protein, offered new perspectives for the eradication of ADV. To eradicate the virus, it is essential to be able to differentiate between infected and vaccinated pigs. For this purpose the blocking ELISA (immunoenzyme test) has been developed to detect antibodies that block the reaction of monoclonal antibodies to epitope on $\mathrm{gE}$ of ADV (Van Oirschot et al. 1990; Kinker et al. 1997).

Poxviridae are the largest of known human and animal viruses. It was first noted in 1978 that inactivated poxviruses might possess immunostimulating capacity (May r et al. 1978). Among these, parapoxovis virus preparations have been shown to reduce clinical signs of viral diseases and stress-mediated diseases in different species of animals (Ky riakis et al. 1998; Castrucci et al. 2000; Winnicka et al. 2000). The prophylactic application of inactivated parapoxovis virus (Baypamun, Bayer AG, Leverkusen, Germany) has been shown to induce strong proliferation of peripheral blood mononuclear cells (PBMC) (Fachinger et al. 2000). Such in vivo immunostimulating capacity was also in part demonstrated in vitro.

The aim of our study was to evaluate the non-specific immunoprophylactic effect in Baypamun treated pigs in correlation with pigs vaccinated with $\mathrm{gE}^{-}$vaccine and control pigs after exposure to pigs challenged with wild type ADV.

\section{Materials and Methods}

Pigs

Twenty 6-week-old clinically healthy crossbred pigs were purchased from a large-scale swine farm Dubravica, near Zagreb, Croatia. Pigs were randomly assigned to four experimental groups (I, II, III and IV) comprising five animals each. Pigs were clinically examined and weighed daily. Each group of pigs was housed in an isolation unit under identical conditions. They were fed concentrates and watered ad libitum.

Immune response modifier (IRM)

A preparation of chemically inactivated Parapoxvirus ovis strain D 1701 (containing $10^{6.75} \mathrm{TCID}_{50}$ per dose of $2 \mathrm{ml}$ ), commercially known as Baypamun (BPM, Bayer, Leverkusen, Germany) was used for non-specific immunization.

Non-specific/specific immunization and challenge infection

The pigs from group I were intramuscularly treated twice (on Days -30 and -15) with attenuated $\mathrm{gE}^{-}$vaccine (Ay-vac, Pliva, Zagreb, Croatia) prepared from Bartha K-61 strain of ADV. Five pigs in group II were intramuscularly treated either three times (on Days $-4,-2$, and 0 ) with $2 \mathrm{ml}$ of BPM. Animals of the group III were infected (on Day 0) by intranasal inoculation of $1 \mathrm{ml}$ of suspension (1:10 dilution) containing $10^{5.8} \mathrm{TCID}_{50} / \mathrm{ml}_{\mathrm{of}}$ virulent Northern Ireland Aujeszky's-3 (NIA-3) strain of ADV. The fourth group of pigs (served as control) was mixed along with the pigs from group I, and group II and with the directly infected pigs (group III) for 4 days after challenge infection. Four days post-infection the pigs were separated and observed for additional 17 days.

Samples

Blood was collected by venepuncture into heparinized syringes $(20 \mathrm{ml})$ and tubes $(10 \mathrm{ml})$. The samples were used either freshly for the isolation of PBL or after processing and storing at $-20^{\circ} \mathrm{C}$ for specific serum antibody detection. Nasal swabs were taken throughout the observation period.

Virus detection

The ADV was detected from nasal swabs by cytopathic effect in RK-13 cell culture.

Specific antibody detection

Specific antibodies to ADV and gE antibodies in the sera of tested pigs were detected by a commercial ELISA test kit (HerdChek) according to producer's recommendations (IDEXX Labs, Inc.). 
Isolation of PBL and lymphocyte stimulation test (LST)

The PBL were isolated by density gradient centrifugation (Valpotić et al. 1986) and cultured with or without mitogens, as previously detailed (Valpotić et al. 1989). Lymphocytes $\left(2 \times 10^{5}\right.$ cells per well) were stimulated with either $10 \mu \mathrm{g} / \mathrm{ml}$ of phytohemagglutinin (PHA; Wellcome) or $5 \mu \mathrm{g} / \mathrm{ml}$ of pokeweed mitogen (PWM; ICN Biomedicals) for $72 \mathrm{~h}$. Pulse labelling of stimulated cells was performed by adding $1 \mu \mathrm{Ci}$ per well of ${ }^{3} \mathrm{H}$-thymidine (specific activity: $5 \mu \mathrm{Ci} / \mathrm{mM}$; Amersham, UK) $18 \mathrm{~h}$ prior to harvesting. The cells were then harvested by Skatron cell harvester (Skatron, Lier, Norway), dried on Skatron GF/C filters and transferred into counting vials with $3 \mathrm{ml}$ of scintillation liquid (Merck, Darmstadt, Germany). Incorporation of ${ }^{3} \mathrm{H}$-thymidine into newly synthesized DNA of stimulated cells was measured by $\beta$-scintillation counter Delta 300 (Nuclear, Chicago, USA) and expressed as counts per minute (CPM). The CPM of triplicate cultures was calculated as the mean \pm SD stimulation index (SI) values (experimental, stimulated CPM/control, unstimulated CPM).

Statistical analysis

The levels of significance were determined by $t$-test using computer program Microsoft Excel 5.0 (Microsoft Corporation, USA).

\section{Results}

\section{Clinical examinations}

Data on clinical examinations (body temperature, tremor, diarrhoea), mortality rate and necropsy findings in pigs are presented in Table 1. Necropsy findings were more prominently expressed in the pigs of group III, while less intensive findings were evident in the pigs of groups IV and II. In pigs of group I such findings were not expressed.

Table 1

Data on clinical examination, mortality rate and necropsy findings in experimental pigs

\begin{tabular}{|c|c|c|c|c|c|}
\hline 苛 & $\begin{array}{c}\text { Average } \\
\text { group body } \\
\text { temperature } \\
\left({ }^{\circ} \mathrm{C}\right)\end{array}$ & $\begin{array}{l}\text { No. of pigs } \\
\text { with } \\
\text { tremor/No. of } \\
\text { pigs tested }\end{array}$ & $\begin{array}{c}\text { No. of } \\
\text { diarrhoeic } \\
\text { pigs/No. of } \\
\text { pigs tested }\end{array}$ & $\begin{array}{l}\text { No. of dead } \\
\text { pigs/No. of } \\
\text { pigs } \\
\text { tested }\end{array}$ & Gross pathology findings at necropsy \\
\hline $\begin{array}{c}\text { Direct } \\
\text { infection } \\
\text { (D. I.) }\end{array}$ & 40.3 & $5 / 5$ & $3 / 5$ & $3 / 5$ & $\begin{array}{c}\text { conjunctivitis/rhinitis, } \\
\text { swollen hemorrhagic lymph nodes of } \\
\text { upper respiratory tract, acute } \\
\text { lymphadenitis, } \\
\text { hyperaemia and oedema of } \\
\text { brain and meninges, } \\
\text { pulmonary oedema, } \\
\text { hemorrhagia and focal } \\
\text { necrosis in lungs, } \\
\text { emphysema, focal necrosis } \\
\text { in liver, enteritis }\end{array}$ \\
\hline $\begin{array}{c}\text { Contact } \\
\text { infection } \\
\text { (C. I.) }\end{array}$ & 40.24 & $5 / 5$ & $2 / 5$ & $1 / 5$ & $\begin{array}{l}\text { Less intensive changes } \\
\text { than in D. I. pigs }\end{array}$ \\
\hline Ay-vac & 39.76 & $0 / 5$ & $1 / 5$ & $0 / 5$ & - \\
\hline BPM & 39.84 & $3 / 5$ & $0 / 5$ & $1 / 5$ & $\begin{array}{l}\text { Less intensive changes } \\
\text { than in D. I. pigs }\end{array}$ \\
\hline
\end{tabular}

Data for clinical examination (body temperature, tremor, diarrhoea) are expressed as average group values calculated from Day 0 to Day 14

Average group body weight gains in pigs are shown in Table 2 . The highest body weight gain was observed in groups I and II on Days 0 and 14. In the pigs from group IV, the body weight gain was the lowest from Day 4 to Day 14 as compared to those from groups I and 
II. The pigs from group III had statistical significantly $(P<0.05)$ lower body weight gain on Day 4 in comparison to all other groups.

Table 2

Average group body weight gain in experimental pigs

\begin{tabular}{|c|c|c|c|c|}
\hline \multirow{2}{*}{ Treatment } & \multicolumn{4}{|c|}{$\begin{array}{c}\text { \% of weight gain in relation to average group body weight } \\
(100 \%) \text { of pigs at Day -30 }\end{array}$} \\
\cline { 2 - 5 } & Day-15 & Day 0 & Day 4 & Day 14 \\
\hline \multirow{2}{*}{ Direct infection } & 44.6 & 69.2 & 73.1 & 97.7 \\
Contact infection & 46.1 & 71.9 & $101.6^{*}$ & 104.4 \\
Ay-vac & 44.4 & 91.1 & $103.2^{*}$ & $148.7^{*}$ \\
BPM & 46.8 & 77.9 & $104.0^{*}$ & 129.8 \\
\hline
\end{tabular}

* Statistically significant $(P<0.05)$ increase of body weight gain in comparison to pigs in group III

Histopathological findings

Histopathological findings of pigs that succumbed to infection or were euthanized are presented in Table 3. The greatest changes were observed in pigs of group III, while those lesions were less intensive in controls (group IV) and BPM-treated pigs (group II). In vaccinated pigs (group I), histopathological changes were either absent or non-specific. Microscopic lesions are most frequently in the CNS. Meninges over affected areas may be thickened because of infiltrates of mononuclear cells. Lymph nodes of respiratory tract were infiltrated with mononuclear cells, lung lesions consisting of haemorrhagic bronchitis, bronchiolitis and alveolitis.

Table 3

Histopathological (HP) findings in experimental pigs

\begin{tabular}{|c|c|c|c|}
\hline 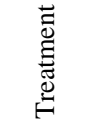 & $\begin{array}{l}\text { No. of pigs that died before } \\
\text { Day } 21 / \text { No. of tested pigs }\end{array}$ & $\begin{array}{c}\text { No. of euthanized } \\
\text { pigs/No. of pigs tested }\end{array}$ & HP findings at necropsy/euthanasia: \\
\hline D. I. & $3 / 5$ & $2 / 5$ & $\begin{array}{l}\text { Meningoencephalitis, perivascular } \\
\text { infiltration of mononuclear cells, } \\
\text { and necrosis of ganglion } \\
\text { cells in the brain. } \\
\text { Hyperaemia/oedema of lungs, } \\
\text { lesions and intracellular } \\
\text { inclusion of bodies in alveolar } \\
\text { epithelium. Focal necrosis in liver, } \\
\text { spleen and lymph nodes of upper } \\
\text { respiratory tract }\end{array}$ \\
\hline C. I. & $1 / 5$ & $4 / 5$ & $\begin{array}{c}\text { Generally milder but similar to those } \\
\text { in D. I. pigs }\end{array}$ \\
\hline Ay-vac & $0 / 5$ & $5 / 5$ & - \\
\hline BPM & $1 / 5$ & $4 / 5$ & $\begin{array}{c}\text { The changes in pig that died were } \\
\text { similar to those in D. I. group of pigs, } \\
3 \text { euthanized pigs had milder changes, } \\
\text { one euthanized pig had no or non- } \\
\text { specific HP findings }\end{array}$ \\
\hline
\end{tabular}


ELISA titers of specific ADV antibodies

Specific antibodies to Aujeszky's disease virus were detected in the vaccinated pigs (group I) 14 days after revaccination, and their titer progressively increasing over the two subsequent weeks (Fig. 1). In BPM-treated pigs (group II) the antibodies were also detected two weeks after revaccination and slowly increased. On Day -15 and Day 0 no specific antibodies were detected in sera of pigs assigned to the group intended for direct intranasal infection (group III). Three of five control pigs (group IV) developed antibodies to ADV 14 days after mixing with pigs from group III (Table 4).

In most pigs maternal antibodies were detected on the day of vaccination, but which disappeared after two or four weeks (Fig. 1).

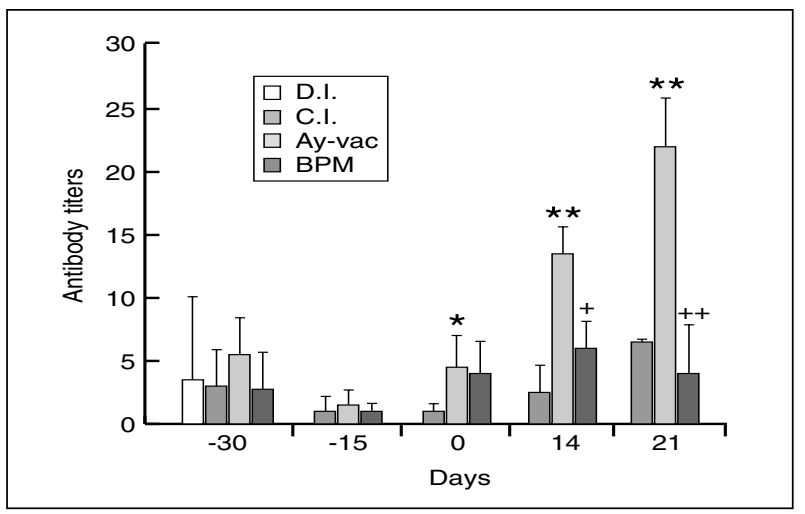

Fig. 1. ELISA titers of specific ADV serum antibodies in experimental pigs

Significantly different at $* P<0.05 ; * * P<0.01$ than in control pigs (group IV)

Significantly different at ${ }^{+} P<0.05 ;^{++} P<0.01$ between group I and group II.

The gE antibodies were also detected in the sera of tested pigs. The gE antibodies were found in two control pigs (group IV) two weeks after infection, and in one more pig three weeks post-infection. In the sera of BPM-treated pigs (group II) the gE antibodies were also present in two pigs, two and three weeks following infection. In the pigs from group III no $\mathrm{gE}$ antibodies were detected. However, the $\mathrm{gE}$ antibodies were detected only in one vaccinated pig from group I, two weeks after infection (Table 4).

Table 4

Specific antibodies to ADV, virus detection and $\mathrm{gE}$ antibodies to ADV in experimental pigs

\begin{tabular}{|c|c|c|c|c|c|c|}
\hline Group & & Day -30 & Day -15 & Day 0 & Day 14 & Day 21 \\
\hline \multirow{3}{*}{ I } & \multirow{3}{*}{$($ Ay-vac) } & $3 / 5^{a}$ & $2 / 5$ & $4 / 5$ & $5 / 5$ & $5 / 5$ \\
\hline & & $0 / 5^{b}$ & $0 / 5$ & $0 / 5$ & $0 / 5$ & $0 / 5$ \\
\hline & & $0 / 5^{\mathrm{c}}$ & $0 / 5$ & $0 / 5$ & $1 / 5$ & $1 / 5$ \\
\hline \multirow{3}{*}{ II } & \multirow{3}{*}{ (BPM) } & $3 / 5$ & $1 / 5$ & $3 / 5$ & $4 / 5$ & $4 / 4$ \\
\hline & & $0 / 5$ & $0 / 5$ & $0 / 5$ & $0 / 5$ & $0 / 4$ \\
\hline & & $0 / 5$ & $0 / 5$ & $0 / 5$ & $2 / 5$ & $2 / 4$ \\
\hline \multirow{3}{*}{ III } & \multirow{3}{*}{ (Direct infection) } & $2 / 5$ & $0 / 5$ & $0 / 5$ & $0 / 4$ & $0 / 2$ \\
\hline & & $0 / 5$ & $0 / 5$ & $0 / 5$ & $4 / 4$ & $2 / 2$ \\
\hline & & $0 / 5$ & $0 / 5$ & $0 / 5$ & $0 / 4$ & $0 / 2$ \\
\hline \multirow{3}{*}{ IV } & \multirow{3}{*}{ (Control) } & $4 / 5$ & $1 / 5$ & $1 / 5$ & $3 / 5$ & $3 / 4$ \\
\hline & & $0 / 5$ & $0 / 5$ & $0 / 5$ & $3 / 5$ & $3 / 4$ \\
\hline & & $0 / 5$ & $0 / 5$ & $0 / 5$ & $2 / 5$ & $3 / 4$ \\
\hline
\end{tabular}

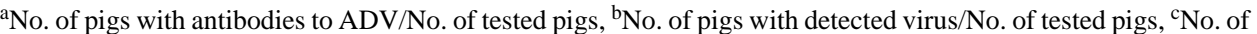
$\mathrm{gE}$ seropositive pigs/No. of tested pigs 
The ADV was detected from nasal swabs of all live pigs in group III and in three control pigs (group IV) on Days 14 and 21 after inoculation. In pigs from groups I and II the ADV was not detected (Table 4).

\section{Lymphocyte stimulation test}

According to obtained results, T-cell responsiveness (consistent with PHA-induced PBL proliferation; Fig. 2.) was highly stimulated in Ay-vac vaccinated pigs (group I) between Day -30 $(P<0.01)$ and Day -15 $(P<0.05)$ compared to control pigs (group IV). On Day 0, responses of PBL in pigs from group I to PHA were significantly lower $(P<0.05)$ than in control pigs (group IV). In the Baypamun-treated group (group II) the response of PBL to PHA stimulation was elevated, although not significantly. Similarly, the higher response of B-cells (consistent with PWM-induced proliferation; Fig. 3.) was obtained in BPM-treated pigs on Day 0, but was significantly lower in the group I $(P<0.05)$. Between Day 8 and Day 13 there was an increase of B-cell responses in pigs from group I in comparison with control pigs (group IV), but proliferation of B-cells in BMP-treated pigs (group II) tended to decrease at the end of the experiment.

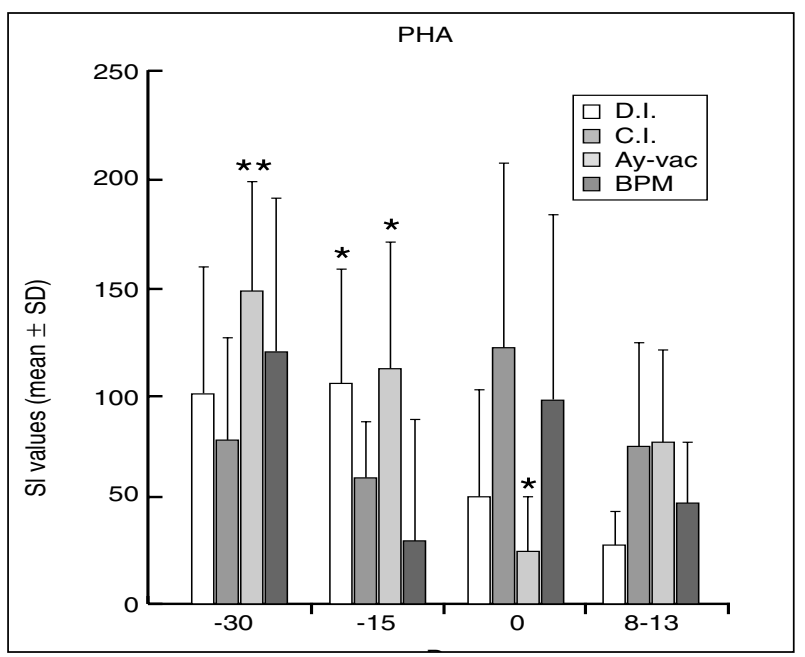

Fig. 2. Mean ( SD) PHA-induced proliferative response (expressed as stimulation index; SI) of PBL in experimental pigs. Significantly different at $* P<0.05 ; * * P<0.01$ in comparison with control pigs (group IV).

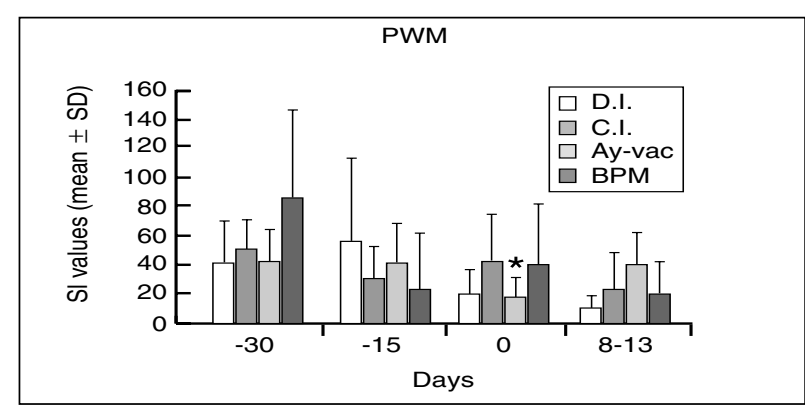

Fig. 3. Mean ( SD) PWM-induced proliferative response (expressed as stimulation index; SI) of PBL in experimental pigs. Significantly different at $* P<0.05$ than in control pigs (group IV). 


\section{Discussion}

Use of BPM in this model, rather as an adjuvant than as IRM, would be a more appropriate approach for enhancing both non-specific and specific immune responses of pigs immunized with $\mathrm{gE}^{-}$vaccine against Aujeszky's disease. However, the obtained results are less obvious, but encouraging, with regard to the non-specific immunostimulatory effect of BPM, since vaccinated and Baypamun-treated pigs were better protected from, or less affected by, contact infection, respectively.

Mayr and Mayr (1995) took ADV as a challenge model to investigate the efficacy of pox-inducers in isolated blood cells and liver cells. They found that pox-inducers increased phagocytosis, NK-cells and the thymidinkinase activity in liver cells. Investigations on "cytokine release" illustrate that pox-inducers promote the release, respectively, of the production of diverse cytokines that are important for regulation of the immune system.

Fachinger et al. (2000) tested eight inactivated poxvirus strains belonging to three different genera (Orthopoxvirus, Avipoxvirus, and Parapoxvirus) for their capacity to activate cells of porcine innate and specific immune systems in vitro. The results demonstrated that all tested poxviruses possessed an immunostimulating capacity.

In unvaccinated pigs, the presence of maternal immunity did not inhibit the development of a T-cell response after inoculation with ADV (Bouma et al. 1998). T-lymphocytes proliferated abundantly one week after inoculation, and a B-lymphocyte response was observed (De Bruin et al. 1998).

The gE-ELISA is used for differentiation between pigs infected with ADV and vaccinated with gE-negative vaccines (V an Oirschot et al. 1990). The gE-negative deletion mutant vaccines provide a basis for control of this infectious disease (V an Oirsch ot et al. 1988).

In our experiment, specific antibodies to $\mathrm{ADV}$ and $\mathrm{gE}$ antibodies were detected in all vaccinated pigs, which is a result of vaccination and infection.

Rodriguez-Buenfil et al. (2002) also analyzed serum samples for antibodies to ADV in sows and presented a cross-sectional study to determine the prevalence of antibodies in fattening pigs. Sera were analyzed by the screening-ELISA and gE-ELISA tests. None of the piglets was positive to antibodies against field virus risk-suggesting that the strategy of vaccinating only breeding animals reduced the ADV infection of piglets.

Rodriguez-Arrioja et al. (1999) described cases of ADV infection at one pig-fattening farm. Histopathological findings on that farm were very similar to those in pigs of our experiment especially in hyperaemia of lungs and interstitial pneumonia.

The highest body weight gain was observed in vaccinated and BPM-treated pigs after vaccination and revaccination. Results by Regula et al. (2000) suggest that sub-clinical infection with this virus was associated with a decrease in average daily weight gain in pigs.

The effects of ADV infection in vivo on lymphocyte functions were controversial. ADV infection suppressed or did not affect lymphocyte proliferation in response to mitogens. (Van Oirschot 1979; Flaming et al. 1989; Page et al. 1992). These inconsistent findings may be due to the differences of strains or infecting doses of virus infection, and health status of the animals. In a recent study, by infecting caesarean-derived colostrumdeprived pigs with a low dose of $\operatorname{ADV}\left(10^{2} \mathrm{TCID}_{50}\right.$ per pig), the infected pigs exhibited a suppression of mitogenic proliferative response of whole blood, but not Ficoll-Hypaque separated PBMC, during the first week post-infection. This comparison was based on the same number of lymphocytes, suggesting that soluble suppressor effectors mediated this suppression (Chinsakchai et Molitor 1994).

Lymphocytes from pigs vaccinated with Ay-vac exhibited increased response to PHA at Day -15 and decreased response at Day 0, compared to the data obtained in other groups of pigs. Since their response to PHA was also significantly increased on Day -30 (day of first 
vaccination), it is unlikely that the vaccine induced increased responses between Day -30 and Day -15. Consistent with this assumption is the decreased response obtained on Day 0. Similarly, lymphocytes from vaccinated pigs reacted to stimulation with PWM, exhibiting the lowest response on Day 0. However, a certain (but not significant) trend of elevation of PWM-induced response was recorded between Days 8-13. Our finding for PHA-induced reactivity is in agreement with the data of S abini et al. (2001) who observed no differences in lymphocyte response to PHA between pigs vaccinated with two inactivated ADV vaccines and control pigs. However, when the cells were pre-stimulated with PHA and LPS prior to infection with ADV, they showed increased susceptibility to the virus (W ang et al. 1988). Additionally, T and B lymphocytes strongly proliferated one week after inoculation with wild type virus NIA-3 (De Bruin et al. 1998).

Taken as a whole, it is obvious that the time course of cellular responses to mitogens did not wholly agree with that obtained for humoral immunity to Ay-vac. This is true at least for the data obtained by parallel testing of both types of responses, i.e. until about 14 days postchallenge infection. Unfortunately, further follow-up was performed only for the presence of specific ADV serum antibodies (until Day 21), due to technical difficulties with cellular samples. However, it seems that an initial trend of higher cellular responsiveness occurred in the vaccine-treated group, as determined between Days 8-13 with both mitogens applied.

Finally, it can be concluded that Baypamun reduced or prevented clinical signs of the disease, such as elevated body temperature, incidence of diarrhoea and weight loss. However, it was less effective than Ay-vac treatment in the immunoprophylaxis of AD in this model system.

The preparation did not affect specific antibody production. However, it increased in vitro PBL responsiveness to PHA (T-cell mitogen) and PWM (mostly B-cell mitogen) on Day 0.

\section{Účinek léčby Baypamunem u viru Aujeszkyho choroby při přenosu ze selat napadených virulentním ADV}

Byl studován účinek léčby Baypamunem u viru Aujeszkyho choroby (Aujeszky's Disease Virus - ADV) při přenosu ze selat napadených virulentním ADV. Dvacet hybridních selat ve stáří 6 týdnů byl rozděleno do 4 stejných skupin a bylo vakcinováno, ošetřeno Baypamunem nebo bylo infikováno ADV. Selata 1. skupiny byla ošetřena $\mathrm{gE}^{-}$ vakcínou proti $A D V$, selata 2. skupiny byla ošetřena Baypamunem jako nespecifickou imunostimulační látkou, selata 3. skupiny byla infikována virulentním kmenem ADV kmen NIA - 3 a 4. skupina byla použita jako kontrolní. Po infikování selat 3. skupiny, byla všechna ustájena pohromadě. Celkové množství protilátek a gE protilátek proti ADV $\mathrm{v}$ séru testovaných selat bylo zjištěno pomocí imunoenzymové analýzy. Byla provedena také izolace PBL a lymfocyty stimulující test. Naše výsledky ukazují, že selata 1. a 2. skupiny byla lépe chráněna před, či méně zasažena, kontaktní infekcí. Signifikantně vyšší mortalita byla zaznamenána u selat 3. skupiny. U této skupiny byly taktéž zjištěny nejintenzivnější patomorfologické změny, nicméně podobné byly též $\mathrm{v}$ 2. a 4. skupině. Výše zmíněná skupina selat měla nižší výskyt průjmů $(0 / 5: 2 / 5)$ a zvýšenou aktivitu T a B buněk ve srovnání s kontrolní skupinou (4.). Ačkoliv Baypamun neovlivňuje produkci specifických protilátek, získané výsledky jsou povzbuzující s ohledem na nespecifický imunostimulační efekt BPM u prasat vystavených kontaktní infekci ADV.

\section{References}

BALASCH, M, PUJOLS, J, SEGALES, J, PLANA-DURAN, J, PUMAROLA, M 1998: Study of the persistence of Aujeszky's disease (pseudorabies) virus in peripheral blood mononuclear cells and tissues of experimentally infected pigs. Vet Microbiol 62: 171-183 
BOUMA, A, DE JONG, MD, KIMMAN, TG 1998: The influence of maternal immunity on the development of the in vitro lymphocyte proliferation response against pseudorabies virus in pigs. Res Vet Sci 64: $167-171$

CASTRUCCI, G, OSBURN, BI, FRIGERI, F, FERRARI, M, SALVATORI, D, LO DICO, M, BARRECA, F 2000: The use of immunomodulators in the control of infectious bovine rhinotracheitis. Comp Immunol Microbiol Infect Dis 23: 163-173

CHINKSAKCHAI, S, MOLITOR, TW 1994: Immunobiology of pseudorabies virus infection in swine. Vet Immunol Immunopathol 43: 107-116

DE BRUIN, MG, DE VISSER, YE, KIMMAN, TG, BIANCHI, AT 1998: Time course of the porcine cellular and humoral immune responses in vivo against pseudorabies virus after inoculation and challenge: significance of in vitro antigenic re-stimulation. Vet Immunol Immunopathol 65: 75-78

EL-AWAR, FY, HAHN, EC 1991: Sources of antibody-dependent cellular cytotoxicity deficiency in young pig leukocytes. J Leukocyte Biol 49:227-235

FACHINGER, V, SCHLAPP, T, STRUBE, W, SCHMEER, N, SAALMULLER, A 2000: Poxvirus-induced immunostimulating effects on porcine leukocytes. J Virol 74: 7943-7951

FLAMING, KP, BLECHA, F, FEDORKA-CRAY, PJ, ANDERSON, GA 1989: Influence of isoprinosine on lymphocyte function in virus-infected feeder pigs. Am J Vet Res 50:1653-1657

HAHN, EC 1991: Pseudorabies virus associated disease and mechanisms of viral immunosuppression. Proc. US Ann. Health Assoc. 407-415

KINKER, DR, SWENSON, LS, WU, LL, ZIMMERMAN, JJ 1997: Evaluation of serological tests for the detection of pseudorabies gE antibodies during early infection. Vet Microbiol 55: 99-106

KLUGE, JP, BERAN, GW, HILL, HT, PLATT, KB 1999: Pseudorabies (Aujeszky's disease). In: STRAW, BE, D'ALLAIRE, S, MENGELING, WL, TAYLOR, DJ (Eds): Diseases of swine. 8th ed. Blackwell Publishing Company, Iowa State Press, Ames, pp. 233-246

KYRIAKIS, SC, TZIKA, ED, LYRAS, DN, TSINAS, AC, SAOULIDIS, K, SARRIS, K 1998: Effect of an inactivated Parapoxvirus based immunomodulator (Baypamun) on post weaning diarrhoea syndrome and wasting pig syndrome of piglets. Res Vet Sci 64: 187-190

MAYR, A, HIMMER, B, BALJER, G, SAILER, J 1978: Erregerunspezifische Prophylaxe und Therapie von Pseudomonas-aeruginosa-Wundinfektion mittels Paramunisierung im Mäusemodell. Zentbl Bakteriol Hyg Parasitenkd Infektionskr Abt 1 Orig Reihe A 176: 506-514

MAYR, B, MAYR, A 1995: Present state of preclinical research on the efficacy and safety of para immunity inducers from poxviruses. Tierarztl Prax 23: 542-552

METTENLEITER, TC 1996: Immunobiology of pseudorabies (Aujeszky's Disease). Vet Immunol Immunopathol 54: 221-229

PAGE, GR, WANG, FI, HAHN, EC 1992: Interaction of pseudorabies virus with porcine peripheral blood lymphocytes. J Leukoc Biol 52: 441-448

REGULA, G, LICHTENSTEIGER, A, MATEUS-PINILLA, NE, SCHERBA, G, MILLER, GY, WEIGEL, RM 2000: Comparison of serologic testing and slaughter evaluation for assessing the effects of sub-clinical infection on growth in pigs. J Am Vet Med Assoc 217: 888-895

RODRIGUEZ-ARRIOJA, GM, SEGALES, J, ROSELL, C, QUINTANA, J, AYLLON, S, CAMPRODON, A, DOMINGO, M 1999: Aujeszky's disease virus infection concurrent with post-weaning multisystemic wasting syndrome in pigs. Vet Rec 144: 152-153

RODRIGUEZ-BUENFIL, JC, ALVAREZ-FLEITES, M, ALZINA-LOPEZ, A, ARJONA-TORRES, MG, SEGURA-CORREA, JC, VILLEGAS-PEREZ, S 2002: Risk factors for Aujeszky's disease in pig herds and detection of field virus antibodies in fattening pigs in the state of Yucatan, Mexico. Prev Vet Med 53: 205-213

SABINI, LI, CERIATTI, F, TORRES, C, SUTIL, S, LARA, L, ROVERA, M, RAMOS, B, RODRIGUEZ, MI 2001: Potency analysis of inactivated vaccines for Aujeszky's disease virus (ADV), strain RC/79: Lymphocyte stimulation in immunized pigs. Rev Latinoam Microbiol 43: 123-129

VALPOTIå, I, GERENâER, M, IILIå, M, BA·Iå, I 1986: In vitro reactivity to mitogens of murine, canine, porcine, equine and human peripheral blood lymphocytes after cryopreservation. Vet arhiv 56: 159-167

VALPOTIå, I, GERENâER, M, BA-Iå, I 1989: In vitro modulating effects of porcine immunoglobulin G on mitogens-induced lymphocyte response in pre-colostral, suckling and weaned piglets. Vet Immunol Immunopathol 22: 113-122

VAN OIRSCHOT, JT 1979: In vitro stimulation of pig lymphocytes after infection and vaccination with Aujeszky's disease virus. Vet Microbiol 3: 255-268

VAN OIRSCHOT, JT, HOUWERS, DJ, RZIHA, HJ, MOONEN, PJLM 1988: Development of an ELISA for detection of antibodies to glycoprotein I of Aujeszky's disease virus: a method for the serological differentiation between infected and vaccinated pigs. J Virol Meth 22: 191-206

VAN OIRSCHOT, JT, WIJSMULLER, JM, DE WAAL, CAH, VAN LITH, PM 1990: A novel concept for the control of Aujeszky's disease: Experiences in two vaccinated pig herds. Vet Rec 17: 159-163

VAN ZAANE, D, BROUWERS, RAM, VAN OIRSCHOT, JT, POL, JMA, KIMMAN, TG 1989: Mucosal immunity of Aujeszky's disease. In: VAN OIRSCHOT, JT (Ed): Vaccination and Control of Aujeszky's Disease. Kluwer Academic Publishers, Brussels-Luxembourg, Hardbound, pp. 139-149 
WANG, FI, PANG, VF, HAHN, EC 1988: Flow cytometric analysis of porcine peripheral blood leukocytes infected with pseudorabies virus. J Leukoc Biol 43: 256-264

WINNICKA, A, KLUCINSKI, W, KAWIAK, J, HOSER, G 2000: Effect of Baypamun on blood leucocytes in normal and dexamethasone-treated goats. J Vet Med A Physiol Pathol Clin Med 47: 385-394 